\title{
Identifikasi Invertebrata di Pantai Ngeden Yogyakarta Sebagai Bahan Pengembangan Multimedia Interaktif Biologi Sekolah Menengah Atas
}

\author{
Fita Murwanti, ${ }^{1,}$, Nur Rokhimah Hanik ${ }^{2}$, Tri Wiharti ${ }^{3}$ \\ ${ }^{123}$ Program Studi Pendidikan Biologi, Universitas Veteran Bangun Nusantara Sukoharjo \\ *Alamat email koresponden: fitamurwanti97@gmail.com \\ diterima: 13 Agustus 2019, disetujui: 16 Agustus 2019, dipublikasikan: 30 September 2019.
}

\begin{abstract}
Abstrak
Penelitian ini betujuan untuk mengetahui jenis-jenis hewan invertebrata di Kawasan Pantai Ngeden desa Krambilsawit kecamatan Saptosari kabupaten Gunung Kidul, Yogyakarta yang dapat digunakan untuk pengembangan multimedia interaktif. Metode penelitian menggunakan metode eksplorasi dengan menerapkan purposive sampling dalam pengambilan stasiun. Teknik pengumpulan data dengan observasi, identifikasi dan dokumentasi. Instrumen penilaian kualitas multimedia interaktif berdasarkan pada aspek materi, media dan pemanfaatan, dengan teknik analisis deskriptif kualitatif. Hasil penelitian ini menunjukkan bahwa di Pantai Ngeden Gunung Kidul, Yogyakarta ditemukan 18 spesies hewan invertebrata yang termasuk ke dalam 5 filum yaitu filum Coelenterata, Annelida, Mollusca, Arthtopoda, dan Echinodermata yang dapat digunakan untuk penyusunan multimedia interaktif dengan materi Invertebrata. Kualitas multimedia interaktif ini ditinjau dari aspek materi diperoleh persentase 95,45\% (sangat valid), aspek media diperoleh persentase 82,29\% (sangat valid), dan aspek pemanfaatan dinilai guru biologi SMA Negeri 1 Bulu diperoleh persentase 96,25\% (sangat valid). Maka dapat disimpulkan bahwa multimedia interaktif ini sangat layak digunakan oleh guru sebagai salah satu media pembelajaran pada materi Invertebrata.
\end{abstract}

Kata Kunci : Invertebrata, Multimedia Interaktif, Biologi

\section{Identification of Invertebrates in Yogyakarta's Ngeden Beach as a Biology Interactive Multimedia Material in High School}

\author{
Fita Murwanti ${ }^{1, *}$, Nur Rokhimah Hanik ${ }^{2}$, Tri Wiharti ${ }^{3}$ \\ ${ }^{123}$ Biology Education Department, Universitas Veteran Bangun Nusantara Sukoharjo \\ *Correspondent's email: fitamurwanti97@gmail.com \\ Accepted: August 13 ${ }^{\text {th }}, 2019$. Approved: August 16 $6^{\text {th }}, 2019$, Published: September 30 ${ }^{\text {th }}, 2019$
}

\begin{abstract}
This study aims to find out the types of invertebrate animals in the Ngeden Coastal Area, Krambilsawit village, Saptosari district, Gunung Kidul district, Yogyakarta, which can be used for the development of interactive multimedia. The research method uses the exploration method by applying purposive sampling in taking stations. Data collection techniques by observation, identification and documentation. Interactive multimedia quality assessment instruments based on aspects of material, media and utilization, with qualitative descriptive analysis techniques. The results of this study indicate that in Ngeden Gunung Kidul Beach, Yogyakarta, 18 species of invertebrate animals were found which are included in the 5 phyla, namely the phylum Coelenterata, Annelida, Mollusca, Arthtopoda, and Echinoderms which can be used for interactive multimedia preparation with Invertebrate material. The quality of this interactive multimedia in terms of the material aspects obtained a percentage of $95.45 \%$ (very valid), the media aspect obtained a percentage of $82.29 \%$ (very valid), and the utilization aspect assessed by the biology teacher of SMA Negeri 1 Bulu obtained a percentage of $96.25 \%$ (very valid). So it can be concluded that this interactive multimedia is very feasible to be used by teachers as one of the learning media on Invertebrate material.
\end{abstract}

Keywords: Invertebrate, Interactive Multimedia, Biology 


\section{PENDAHULUAN}

Pendidikan adalah usaha sadar dan Pendidikan adalah usaha sadar dan terencana untuk mewujudkan suasana belajar dan proses pembelajaran agar peserta didik secara aktif mengembangkan potensi dirinya untuk memiliki kekuatan spiritual keagamaan, pengendalian diri, kepribadian, kecerdasan, akhlak mulia, serta keterampilan yang diperlukan dirinya, masyarakat, bangsa dan negara (UU No. 20 Tahun 2003 tentang SISDIKNAS). Dalam pendidikan di sekolah ada beberapa macam pembelajaran untuk peserta didik, salah satunya yaitu mata pelajaran Biologi. Mata pelajaran Biologi merupakan salah satu cabang Ilmu Pengetahuan Alam yang mempunyai sasaran studi menyangkut isi alam. Pada garis besarnya, isi alam dapat dibedakan menjadi dua macam, yaitu : makhluk hidup dan makhluk tak hidup, Ditinjau dari etimologinya, biologi berasal dari kata bios (hidup) $\operatorname{logos}$ (pembicaraan/ilmu) (Mariyam, 1985). Dalam pelajaran Biologi, diharapkan siswa dapat terlibat secara aktif baik pada saat penyampaian materi maupun secara praktek.

Penggunaan sumber belajar ataupun media pembelajaran secara tepat dalam kegiatan belajar mengajar diharapkan mampu memberikan pengalaman belajar yang baik kepada siswa sehingga mampu terlibat secara aktif dan mampu mengembangkan potensi kognitif dan afektif siswa. Media pembelajaran adalah segala sesuatu yang dapat digunakan untuk menyalurkan pesan dari pengirim ke penerima (Daryanto, 2013;4). Salah satu materiyang perlu penggunaan media dalam proses pembelajarannya adalah pada materi dunia hewan khususnya hewan invertebrata. Hewan invertebrata adalah hewan yang tidak bertulang belakang, invertebrata dibagi menjadi 8 filum yaitu sebagai berikut : Porifera, Ceoelenterata, Platyhelminthes, Nematyhelminthes, Annelida, Arthropoda, Molusca, dan Echinodermata.

Materi dunia hewan termasuk invertebrata di dalamnya merupakan materi yang sulit bagi rata - rata siswa. Hal ini dapat dilihat berdasarkan hasil wawancara dari salah satu sekolah di Kabupaten Sukoharjo yaitu SMA Negeri 1 Bulu, guru mata pelajaran biologi SMA tersebut mengatakan bahwa kesulitan siswa memahami materi dunia hewan dikarenakan banyaknya konten materi yang diajarkan dan saat pembelajaran hanya mengandalkan buku teks yang bersifat verbal. Selain itu nilai ketuntasan siswa yang berhasil masih rendah. Kriteria Ketuntasan Minimal (KKM) yang ditetapkan pada materi dunia hewan di SMA Negeri 1 Bulu yaitu 70. Nilai ketuntasan siswa pada ulangan harian materi dunia hewan di SMA Negeri 1 Bulu untuk MIPA 1 hanya mencapai 40,909 \% (9 tuntas dari 22 siswa) dan untuk siswa yang tidak tuntas mencapai 59,091\% (12 tidak tuntas dari 22 siswa), sedangkan untuk MIPA 2 nilai ketuntasan hanya mencapai 42,857\% (9 tuntas dari 21 siswa) dan untuk siswa yang tidak tuntas mencapai 57,143\% (12 tidak tuntas dari 21 siswa).

Dari hasil wawancara dengan guru Biologi di SMA Negeri 1 Bulu, diketahui bahwa di SMA tersebut sudah menerapkan pembelajaran menggunakan media (LCD) saat proses pembelajaran pada materi dunia hewan, namun penggunaannya masih terbatas berupa penayangan Powerpoint biasa yang membuat siswa hanya pasif dalam proses pembelajaran. Berdasar 
permasalahan tersebut, salah satu solusi untuk meningkatkan nilai ketuntasan siswa dalam materi dunia hewan sub bab Invertebrata adalah dengan pembuatan media pembelajaran yang menuntut siswa dapat aktif sehingga mampu memahami materi dengan baik.

Oleh karena itu, maka peneliti pembelajaran berupa multimedia interaktif sub bab Invertebrata yang merupakan salah satu solusi untuk meningkatkan keaktifan siswa dalam proses pembelajaran. Dimana media tersebut berisi gambar, video, serta soal mengenai materi sub bab Invertebrata berdasarkan penelitian Invertebrata yang memanfaatkan lingkungan Kawasan Pantai Ngeden Gunung Kidul Yogyakarta.

Kawasan Pantai Ngeden terletak di Desa Krambilsawit, Saptosari, Kabupaten Gunung Kidul, Daerah Istimewa Yogyakarta. Lokasinya sekitar 28 kilometer dari pusat kota Wonosari. Kawasan pantai ini memiliki beraneka ragam biota laut, oleh karena itu peneliti tertarik untuk melakukan penelitian di kawasan wisata ini dengan hasil akhir berupa multimedia interaktif yang dapat dimanfaatkan sebagai media pembelajaran.

Multimedia interaktif adalah suatu multimedia yang dilengkapi dengan alat pengontrol yang dapat dioperasikan oleh pengguna, sehingga pengguna dapat memilih apa yang dikehendaki untuk proses selanjutnya. Penelitian (Subiyantoro \& Nugroho, 2018) menyatakan bahwa pengembangan media pembelajaran dapat digunakan sebagi pendukung proses pembelajaran di kelas. Contoh multimedia interaktif adalah powerpoint pembelajaran interaktir, aplikasi game, dan lain - lain (Daryanto, 2013;51). Multimedia interaktif yang akan dibuat berupa gabungan dari powerpoint yang berupa teks, gambar dan video serta sound dan interaksinya dalam video, sedangkan untuk interaktifnya terletak pada adanya latihan soal yang dapat langsung dijawab dan skor yang langsung muncul saat selesai mengerjakan soal tersebut.

\section{METODE}

Lokasi penelitian dilakukan di Kawasan Pantai Ngeden, Desa Krambilsawit, Kecamatan Saptosari, Kabupaten Gunung Kidul, Yogyakarta dan waktu penelitian di mulai pada bulan Mei 2019. Jenis penelitian deskriptif kualitatif menggunakan metode eksplorasi. Subjek penelitian berupa hewan invertebrata.

Prosedur penelitian meliputi : 1) tahap perencanaan meliputi persiapan alat dan bahan-bahan yang diperlukan untuk pembuatan multimedia interaktif; 2) pembuatan produk yaitu pembuatan powerpoint dengan materi, berupa teks, gambar dan grafis yang menarik, kemudian ditambahkan video serta soal; 3) uji validasi oleh ahli, media pembelajaran diuji validasi oleh ahli yang terdiri dari ahli materi, ahli media pembelajaran dan guru biologi (praktisi), uji validasi dilakukan dengan memberikan angket berkaitan dengan media yang dibuat, kemudian skor dari jawaban ahli akan dianalisis, sehingga dapat ditentukan kelayakan dari media yang dibuat; 4) revisi produk dilakukan berdasarkan hasil uji validasi ahli untuk memperbaiki media pembelajaran berupa multimedia interaktif; 5) media pembelajaran berupa multimedia interaktif hasil revisi sudah layak digunakan.

Teknik analisis data menggunakan dua teknik, yaitu analisis deskriptif kualitatif dan analisis deskriptif kuantitatif. 
Analisis deskriptif kualitatif meliputi data yang diperoleh dari hasil wawancara, observasi, dan saran validator. Data diperoleh sebelum terjun ke lapangan atau pada saat tahap analisis kebutuhan dan pada saat pengisian angket di kolom saran dan kritik. Seluruh data dan informasi yang didapat akan dianalisis untuk dijadikan acuan dan pedoman perbaikan dalam pengembangkan multimedia interaktif. Sedangkan, analisis deskriptif kuantitatif digunakan untuk mengetahui kelayakan terhadap produk multimedia interaktif yang dikembangkan. Data yang akan diolah dan dianalisis secara deskriptif kuantitatif diperoleh dari angket yang diberikan kepada para ahli sebagai validator dan guru biologi sebagai pengguna. Berikut jenis angket dalam bentuk deskriptif kuantitatif yang digunakan dalam penelitian ini:

Analisis data angket validasi ahli. Jawaban pada angket validasi ahli menggunakan skala Likert, variabel yang diukur dijabarkan menjadi indikator variabel. Skala Likert terdiri dari skor 1 sampai skor 5 (Sugiyono, 2015). Data hasil validasi selanjutnya dianalisis menggunakan teknik analisis data persentase dengan rumus berikut :

$$
p=\frac{\Sigma n_{x}}{\Sigma n_{y}} 100 \%
$$

Keterangan :

$\mathrm{p}=$ presentase nilai keseluruhan

$\mathrm{n}$ = banyaknya aspek yang dinilai

$\mathrm{x}=$ jumlah skor dari validator untuk seluruh aspek

$\mathrm{y}=$ jumlah skor maksimum untuk seluruh aspek

Data presentase penilaian yang telah diperoleh diubah menjadi data kualitatif deskriptif dengan menggunakan kriteria validitas pada tabel 1 .

Tabel 1. Kualifikasi tingkat pencapaian (Suparno dan Harumi, 2014)

\begin{tabular}{|c|c|c|}
\hline $\begin{array}{c}\text { Tingkat } \\
\text { Pencapaian }\end{array}$ & Kualifikasi & Keterangan \\
\hline $81-100 \%$ & Sangat Valid & $\begin{array}{c}\text { Sangat layak, tidak perlu } \\
\text { direvisi }\end{array}$ \\
\hline $61-80 \%$ & Valid & Layak, tidak perlu direvisi \\
\hline $41-60 \%$ & Cukup Valid & $\begin{array}{c}\text { Kurang layak, perlu } \\
\text { direvisi }\end{array}$ \\
\hline $21-40 \%$ & Kurang valid & Tidak layak, perlu direvisi \\
\hline$<20 \%$ & $\begin{array}{c}\text { Sangat Kurang } \\
\text { Valid }\end{array}$ & $\begin{array}{c}\text { Sangat tidak layak, perlu } \\
\text { direvisi }\end{array}$ \\
\hline
\end{tabular}

\section{HASIL DAN PEMBAHASAN}

Hasil Identifikasi

Kegiatan awal sebelum melakukan pengembangan media pembelajaran multimedia interaktif adalah melakukan pengamatan dan identifikasi hewan invertebrata di Kawasan Pantai Ngeden Gunung Kidul. Adapun identifikasi hewan tersebut sebagai berikut :

Berdasarkan hasil identifikasi, hewan invertebrata yang ditemukan pada saat penelitian sebanyak 18 spesies dan dapat dikelompokkan ke dalam 5 filum. Hasil dari penelitian pada pagi hari dapat dilihat pada tabel 2 .

Tabel 2. Hasil Penelitian Invertebrata pada Pagi Hari

\begin{tabular}{|c|c|c|c|}
\hline No & Nama Spesies & Filum & Jumlah \\
\hline 1 & Physalia physalis & Coelenterata & 2 \\
\hline 2 & Heteractis crispa & Coelenterata & 3 \\
\hline 3 & Perinereis nuntia & Annelida & 3 \\
\hline 4 & $\begin{array}{c}\text { Achantinucella } \\
\text { spirata }\end{array}$ & Mollusca & 8 \\
\hline 5 & Conus virgo & Mollusca & 1 \\
\hline 6 & Trochus niloticus & Mollusca & 1 \\
\hline 7 & $\begin{array}{c}\text { Turbo } \\
\text { argyrostomus }\end{array}$ & Mollusca & 3 \\
\hline 8 & Pyrazus ebeninus & Mollusca & 1 \\
\hline 9 & Littorina lineolata & Mollusca & 2 \\
\hline 10 & $\begin{array}{c}\text { Pagurus } \\
\text { longicarpus }\end{array}$ & Artrhropoda & 3 \\
\hline 11 & Calcinus tibicen & Artrhropoda & 2 \\
\hline
\end{tabular}

Sedangkan untuk hasil penelitian pada siang hari dapat dilihat pada tabel 3. Tabel 3. Hasil Penelitian Invertebrata pada Siang Hari. 


\begin{tabular}{cccc}
\hline No & Nama Spesies & Filum & Jumlah \\
\hline 1 & Heteractis crispa & Coelenterata & 3 \\
2 & Achantinucella & Mollusca & 3 \\
3 & spirata & Mollusca & 1 \\
4 & Conus virgo & Mollusca & 2 \\
5 & Pyrazus ebeninus & Mollusca & 1 \\
6 & Littorina obtusata & Mollusca & 2 \\
7 & Pagurus longicarpus & Artrhropoda & 4 \\
8 & Calcinus tibicen & Artrhropoda & 2 \\
\hline \multicolumn{5}{c}{ TOTAL } & 18 \\
\hline
\end{tabular}

Sedangkan untuk hasil penelitian pada sore hari dapat dilihat pada tabel 4. Tabel 4. Hasil Penelitian Invertebrata pada Sore Hari.

\begin{tabular}{|c|c|c|c|}
\hline No & Nama Spesies & Filum & Jumlah \\
\hline 1 & Physalia physalis & Coelenterata & 1 \\
\hline 2 & Heteractis crispa & Coelenterata & 4 \\
\hline 3 & Perinereis nuntia & Annelida & 2 \\
\hline 4 & $\begin{array}{c}\text { Achantinucella } \\
\text { spirata }\end{array}$ & Mollusca & 4 \\
\hline 5 & Conus virgo & Mollusca & 1 \\
\hline 6 & Turbo argyrostomus & Mollusca & 2 \\
\hline 7 & Pyrazus ebeninus & Mollusca & 1 \\
\hline 8 & Littorina lineolata & Mollusca & 2 \\
\hline 9 & Pagurus longicarpus & Artrhropoda & 4 \\
\hline 10 & Calcinus tibicen & Artrhropoda & 3 \\
\hline 11 & Ocypode occidentalis & Artrhropoda & 8 \\
\hline 12 & Ocypode pallidula & Artrhropoda & 3 \\
\hline 13 & Ophiolephis impressa & Echinodermata & 13 \\
\hline 14 & $\begin{array}{c}\text { Ophiocoma } \\
\text { scolopendrina }\end{array}$ & Echinodermata & 13 \\
\hline 15 & Arbacia punctulata & Echinodermata & 16 \\
\hline 16 & Arbacia lixula & Echinodermata & 14 \\
\hline \multicolumn{3}{|c|}{ TOTAL } & 91 \\
\hline
\end{tabular}

\section{Berdasarkan buku Zoologi} Invertebrata yang ditulis oleh Rusyana (2011), hasil penelitian hewan invertebrata di Kawasan Pantai Ngeden pada bulan Mei tahun 2019 ditemukan 18 spesies hewan invertebrata yang dapat dikelompokkan kedalam 5 filum dan 7 kelas. Jumlah spesies yang didapat bervariasi dari setiap filum, antara lain filum Coelenterata kelas Hydrozoa 1 spesies, filum Coelenterata kelas Anthozoa 1 spesies, filum Annelida kelas Polychaeta 1 spesies, filum Mollusca kelas Gastropoda 7 spesies, filum Arthropoda kelas Crustacea 4 spesies, filum Echinodermata kelas Ophiuroidea 2 spesies, filum Echinodermata kelas Echinoidea 2 spesies.
Jumlah spesies diatas memiliki jumlah yang berbeda pada waktu pagi, siang dan sore hari. Spesies yang diperoleh pada pagi hari di stasiun 1 yaitu 9 individu, stasiun 2 yaitu 15 individu, stasiun 3 yaitu 5 individu. Total seluruh hewan yang ditemukan pada pagi hari yaitu 29 individu. Banyaknya spesies yang diperoleh pada siang hari di stasiun 1 yaitu 10 individu, stasiun 2 yaitu 5 individu, stasiun 3 yaitu 3 individu. Total seluruh spesies yang ditemukan pada siang hari yaitu 18 individu. Banyaknya spesies yang diperoleh pada sore hari di stasiun 1 yaitu 32 individu, stasiun 2 yaitu 36 individu, stasiun 3 yaitu 23 individu. Total seluruh hewan yang ditemukan pada sore hari yaitu 91 individu.

Selain identifikasi hewan, dalam penelitian ini dilakukan pengukuran faktor lingkungan yang mempengaruhi kehidupan invertebrata, meliputi pengukuran suhu air, suhu darat, $\mathrm{pH}$, dan Substrat. Hasil pengukuran $\mathrm{pH}$ dan substrat dapat dilihat pada tabel 5 .

Tabel 5. Hasil pH dan Substrat

\begin{tabular}{|c|c|c|c|c|c|}
\hline No & Stasiun & Pagi & $\begin{array}{c}\mathrm{pH} \\
\text { Siang }\end{array}$ & Sore & Substrat \\
\hline 1 & $\begin{array}{c}\text { 1a (Batas } \\
\text { barat pantai) }\end{array}$ & 8 & 8 & 7 & Pasir kasar \\
\hline 2 & $1 b$ & 7 & 7 & 7 & Pasir kasar \\
\hline 3 & $1 \mathrm{c}$ & 8 & 7 & 7 & $\begin{array}{c}\text { Pasir } \\
\text { berlumpur }\end{array}$ \\
\hline 4 & $\begin{array}{l}\text { 2a (Tengah } \\
\text { pantai) }\end{array}$ & 7 & 7 & 7 & Pasir kasar \\
\hline 5 & $2 b$ & 7 & 7 & 7 & Pasir kasar \\
\hline 6 & $2 \mathrm{c}$ & 8 & 7 & 7 & $\begin{array}{c}\text { Pasir } \\
\text { berlumpur }\end{array}$ \\
\hline 7 & $\begin{array}{c}\text { 3a (Batas } \\
\text { Timur pantai) }\end{array}$ & 7 & 7 & 7 & Pasir kasar \\
\hline 8 & $3 b$ & 7 & 7 & 7 & Pasir kasar \\
\hline 9 & $3 c$ & 7 & 7 & 7 & $\begin{array}{c}\text { Pasir } \\
\text { berlumpur }\end{array}$ \\
\hline
\end{tabular}

Pengukuran faktor berupa suhu air dan suhu darat dapat dilihat pada tabel 6 .

Tabel 6. Hasil Pengukuran suhu air dan suhu darat 


\begin{tabular}{|c|c|c|c|c|c|c|c|}
\hline \multirow{3}{*}{ No } & \multirow{3}{*}{ Stasiun } & \multicolumn{6}{|c|}{ Suhu } \\
\hline & & \multicolumn{2}{|c|}{ Pagi } & \multicolumn{2}{|c|}{ Siang } & \multicolumn{2}{|c|}{ Sore } \\
\hline & & Darat & Air & Darat & Air & Darat & Air \\
\hline 1 & 1a (Batas barat pantai) & $31^{\circ} \mathrm{C}$ & - & $33^{0} \mathrm{C}$ & - & $29^{0} \mathrm{C}$ & - \\
\hline 2 & $1 \mathrm{~b}$ & $30^{\circ} \mathrm{C}$ & $25^{\circ} \mathrm{C}$ & $32^{\circ} \mathrm{C}$ & $24^{0} \mathrm{C}$ & $30^{\circ} \mathrm{C}$ & $23^{\circ} \mathrm{C}$ \\
\hline 3 & $1 \mathrm{c}$ & $30^{\circ} \mathrm{C}$ & $24^{\circ} \mathrm{C}$ & $31^{\circ} \mathrm{C}$ & $25^{\circ} \mathrm{C}$ & $29^{\circ} \mathrm{C}$ & $24^{0} \mathrm{C}$ \\
\hline 4 & 2a (Tengah pantai) & $32^{\circ} \mathrm{C}$ & - & $32^{\circ} \mathrm{C}$ & - & $28^{\circ} \mathrm{C}$ & - \\
\hline 5 & $2 b$ & $29^{\circ} \mathrm{C}$ & $24^{\circ} \mathrm{C}$ & $33^{\circ} \mathrm{C}$ & $24^{\circ} \mathrm{C}$ & $31^{\circ} \mathrm{C}$ & $24^{\circ} \mathrm{C}$ \\
\hline 6 & $2 \mathrm{c}$ & $31^{\circ} \mathrm{C}$ & $24^{\circ} \mathrm{C}$ & $30^{\circ} \mathrm{C}$ & $25^{\circ} \mathrm{C}$ & $28^{0} \mathrm{C}$ & $24^{0} \mathrm{C}$ \\
\hline 7 & 3a (Batas Timur pantai) & $30^{\circ} \mathrm{C}$ & - & $36^{\circ} \mathrm{C}$ & - & $29^{\circ} \mathrm{C}$ & - \\
\hline 8 & $3 b$ & $28^{\circ} \mathrm{C}$ & $24^{\circ} \mathrm{C}$ & $40^{\circ} \mathrm{C}$ & $26^{0} \mathrm{C}$ & $31^{0} \mathrm{C}$ & $24^{\circ} \mathrm{C}$ \\
\hline 9 & $3 \mathrm{c}$ & $29^{\circ} \mathrm{C}$ & $24^{\circ} \mathrm{C}$ & $30^{\circ} \mathrm{C}$ & $25^{\circ} \mathrm{C}$ & $28^{\circ} \mathrm{C}$ & $24^{\circ} \mathrm{C}$ \\
\hline
\end{tabular}

invertebrata yang ditemukan tersebut dipengaruhi oleh beberapa faktor lingkungan yang sesuai atau tidak. Faktor lingkungan yang mempengaruhi keberadaan hewan invertebrata antara lain yaitu suhu darat, suhu air, $\mathrm{pH}$ dan substrat. Setelah dilakukan pengukuran diperoleh bahwa suhu air rata - rata pada pagi hari yaitu $24{ }^{\circ} \mathrm{C}$, suhu darat pada pagi hari yaitu $30^{\circ} \mathrm{C}$, suhu air pada siang hari $25^{\circ} \mathrm{C}$, suhu darat pada siang hari yaitu $35{ }^{\circ} \mathrm{C}$ sedangkan suhu air pada sore hari yaitu $24^{\circ} \mathrm{C}$ dan suhu darat pada sore hari adalah $29^{\circ} \mathrm{C}$.

Suhu sangat berpengaruh terhadap pertumbuhan hewan, suhu optimal yaitu antara $20^{\circ} \mathrm{C}-30^{\circ} \mathrm{C}$ (Upikoh, 2007). Oleh karena itu banyak ditemukan hewan pada saat pengamatan pagi hari dan sore hari, namun sedikit pada siang hari, hal ini dikarenakan aktivitas hewan menjadi terbatas ketika suhu lebih dari $30{ }^{\circ} \mathrm{C}$. Sedangkan, Clark (1946) dalam Toha (2008), mengemukakan bahwa suhu yang cocok untuk perkembangan Echinodermata yaitu dengan kisaran $28^{\circ} \mathrm{C}-31^{\circ} \mathrm{C}$, hal ini sesuai hasil pengamatan bahwa banyak ditemukan bintang ular Ophiolephis impressa dan Ophiocoma scolopendrina, serta bulu babi Arabacia punctulata dan Arbacia lixula pada saat sore hari, dimana suhu rata - rata $29^{\circ} \mathrm{C}$.

Pengukuran $\mathrm{pH}$ rata - rata pada pagi hari yaitu $8, \mathrm{pH}$ pada siang hari yaitu 7 sedangkan akuatik sangat sensitif terhadap perubahan $\mathrm{pH}$. Berdasarkan hasil pengukuran tersebut nilai $\mathrm{pH}$ tersebut, di Kawasan Pantai Ngeden, Gunung Kidul masih sesuai dengan habitat hewan invertebrata akuatik, dimana menurut Effendi (2003) sebagian besar biota akuatik dapat berkembang baik dengan nilai $\mathrm{pH} 7-8,5$.

Pengukuran substrat di Kawasan Pantai Ngeden, Gunung Kidul di stasiun 1a, 2a, dan 3a yaitu pasir kasar, sedangkan substrat di stasiun $1 b, 2 b, 3 b$ dan stasiun $1 c$, 2c, 3c yaitu pasir berlumpur. Substrat adalah permukaan tempat organisme hidup, terutama untuk menetap atau bergerak, atau benda-benda padat tempat organisme menjalankan seluruh atau sebagian hidupnya dan berpengaruh terhadap keanekaragaman hewan invertebrata (Susanto, 2000). Pada penelitian ini terdapat dua substrat yang berbeda yaitu pasir kasar dan berlumpur. Pasir kasar banyak ditemukan hewan filum Arthropoda, karena banyak dari filum Arthropoda seperti Pagurus longicarpus dan Calcinus tibicen dapat bebas bergerak. Sedangkan pada substrat berlumpur ditemukan hewan filum Annelida seperti kelabang laut Perinereis nuntia yang bersembunyi di daerah berlumpur, serta hewan seperti bintang ular Ophiolephis impressa dan Ophiocoma scolopendrina, juga bulu babi Arbacia punctulata dan Arbacia lixula banyak ditemukan di pasir berlumpur yang ditumbuhi lamun sesuai 
dengan Nybakken (1988) yang mengatakan bahwa echinodermata dapat hampir di seluruh perairan, namun paling banyak ditemukan di pasir berlumpur yang ditumbuhi lamun.

\section{Multimedia Interaktif}

Pembuatan media pembelajaran berupa multimedia interaktif ini melewati beberapa tahapan, yaitu 1) perencanaan pembuatan produk, setelah dilakukan identifikasi hewan invertebrata di Kawasan Pantai Ngeden dan diperoleh hasil identifikasi, maka selanjutnya adalah merencanakan untuk pembuatan produk yaitu multimedia interaktif materi hewan invertebrata yang meliputi 3 tahapan. Pertama, persiapan alat, alat-alat yang digunakan dalam pembuatan media antara lain meliputi laptop, alat tulis dan kamera. Laptop digunakan untuk membuat aplikasi multimedia interaktif, alat tulis digunakan untuk menulis hasil identifikasi, dan kamera digunakan untuk pembuatan video dan pemotretan. Kedua, persiapan bahan, bahan yang digunakan dalam multimedia interaktif meliputi hasil identifikasi hewan invertebrata di Kawasan Pantai Ngeden dan buku-buku materi mengenai hewan invertebrata. Ketiga, persiapan aplikasi, aplikasi yang digunakan dalam pembuatan multimedia interaktif antara lain Microsoft Powerpoint 2010 dengan Visual Basic for Aplications (VBA), Photoscape dan Wondershare Filmora Video Editor. Microsoft Powerpoint 2010 dengan Visual Basic for Aplications (VBA) ini digunakan sebagai pembuatan media pembelajaran berupa multimedia interaktif, Photoscape digunakan untuk mengedit foto, sedangkan Wondershare Filmora Video Editor ini digunakan sebagai aplikasi untuk mengedit video yang digunakan untuk media pembelajaran berupa multimedia interaktif;
2) pembuatan produk, pembuatan multimedia interaktif diawali dengan pembuatan Powerpoint Presentation semenarik mungkin dengan materi hewan invertebrata berupa teks, gambar-gambar hewan hasil identifikasi dan video hasil edit.

Setelah pembuatan Powerpoint Presentation, selanjutnya adalah pembuatan soal interaktif, soal-soal yang digunakan adalah soal-soal berfikir kritis. Soal-soal ini kemudian dibuatkan kedalam Powerpoint berbeda dan ditambahkan dengan script VBA serta action, sehingga membuat soal dapat menampilkan skor secara langsung setelah selesai menjawab soal-soal tersebut; 3)uji validasi ahli, setelah dihasilkan produk media pembelajaran berupa multimedia interaktif materi hewan invertebrata, selanjutnya media di uji kevalidannya oleh ahli materi, ahli media, dan guru biologi. alidasi ahli materi dilakukan oleh dosen Pendidikan Biologi Universitas Veteran Bangun Nusantara Sukoharjo. Beliau memberikan beberapa masukan sebagai revisi dari media pembelajaran yang diujikan, antara lain memperjelas materi setiap filum, sebaiknya pembagian kelas dalam bentuk bagan disertai ciri setiap kelasnya, dan memperbaiki soal agar lebih sesuai dengan indikator. Validasi ahli media dilakukan oleh dosen Pendidikan Biologi Universitas Veteran Bangun Nusantara Sukoharjo. Beliau memberikan masukan sebagai revisi dari media pembelajaran yang diujikan yaitu untuk memperbesar tampilan video atau gambar pada multimedia interaktif.Validasi ahli materi dilakukan oleh salah ssatu Guru Biologi di SMA Negeri 1 Bulu. Beliau memberikan beberapa masukan sebagai revisi dari media pembelajaran yang diujikan, antara 
lain untuk meminimalkan tulisan diluar diagram atau bagan dan untuk memberi hyperlink pada peta konsep ke setiap filum sehingga materi lebih mudah diakses, dari hasil uji validasi media tentunya terdapat beberapa revisi yang digunakan sebagai perbaikan. Revisi produk dilakukan agar media pembelajaran yang dibuat lebih menarik dan sesuai dengan kebutuhan siswa; 4) produk hasil revisi, setelah melakukan revisi, penilaian ketiga ahli menyatakan bahwa media pembelajaran berupa multimedia interaktif Sangat Layak untuk digunakan sebagai media pembelajaran yang valid. Dengan hasil analisis sebagai berikut:

Ahli materi, validasi dilakukan dengan memberikan kuesioner kepada validator. Kuesioner berisi instrumen penilaian berupa pertanyaan terstuktur beserta rubrik penilaian, kolom saran dan kolom kesimpulan dari validator. Hasil dari validasi media pembelajaran multimedia interaktif dapat dilihat pada tabel 7 berikut Tabel 7. Hasil Validasi oleh Ahli Materi

\begin{tabular}{ccc}
\hline Jumlah Skor & Presentase & $\begin{array}{c}\text { Kategori } \\
\text { Kevalidan }\end{array}$ \\
\hline 42 & $95,45 \%$ & Sangat Valid \\
\hline
\end{tabular}

Perolehan skor penilaian validator sebanyak 42, skor tersebut kemudian dianalisis dengan menggunakan teknis analisis data presentase yaitu skor yang diperoleh dibagi dengan skor maksimal kemudian dikonversi dalam bentuk presentase. Skor maksimal dalam penilaian multimedia interaktif ini adalah 44. Setelah dikonversi dalam bentuk presentase, skor menjadi 95,45\%. Menurut Suparno dalam Harumi (2014), presentase tersebut menunjukkan bahwa multimedia interaktif yang telah disusun masuk kategori tingkat validasi yang pertama yaitu antara $80 \%$ $100 \%$, skor dan presentase kuesioner tersebut menyatakan bahwa media pembelajaran multimedia interaktif yang telah disusun memiliki kategori yang sangat valid dan siap dimanfaatkan sebagai salah media pembelajaran di SMA. Ahli media, validasi dilakukan dengan memberikan kuesioner kepada validator. Kuesioner berisi instrumen penilaian berupa pertanyaan terstuktur beserta rubrik penilaian, kolom saran dan kolom kesimpulan dari validator. Hasil dari validasi media pembelajaran multimedia interaktif dapat dilihat pada tabel 8 berikut. Tabel 8. Hasil Validasi oleh Ahli Media

\begin{tabular}{ccc}
\hline Jumlah Skor & Prosentase & $\begin{array}{c}\text { Kategori } \\
\text { Kevalidan }\end{array}$ \\
\hline 79 & $82,29 \%$ & Sangat Valid \\
\hline
\end{tabular}

Perolehan skor penilaian validator sebanyak 79, skor tersebut kemudian dianalisis dengan menggunakan teknis analisis data presentase yaitu skor yang diperoleh dibagi dengan skor maksimal kemudian dikonversi dalam bentuk presentase. Skor maksimal dalam penilaian multimedia interaktif ini adalah 96. Setelah dikonversi dalam bentuk presentase, skor menjadi 82,29\%. Menurut Suparno dalam Harumi (2014), Presentase tersebut menunjukkan bahwa multimedia interaktif yang telah disusun masuk kategori tingkat validasi yang pertama yaitu antara $80 \%$ $100 \%$, skor dan presentase kuesioner tersebut menyatakan bahwa media pembelajaran multimedia interaktif yang telah disusun memiliki kategori yang sangat valid dan siap dimanfaatkan sebagai salah media pembelajaran di SMA. Terakhir, valisi oleh guru Biologi, sebagai validator guru biologi dari SMA Negeri 1 Bulu. Validasi dilakukan dengan memberikan kuesioner kepada validator. Kuesioner berisi instrumen penilaian berupa pertanyaan terstuktur beserta rubrik penilaian, kolom saran dan kolom kesimpulan dari validator. Hasil dari 
validasi media pembelajaran multimedia interaktif dapat dilihat pada tabel 9 berikut Tabel 9. Hasil Validasi oleh Guru Biologi

\begin{tabular}{ccc}
\hline Jumlah Skor & Prosentase & $\begin{array}{c}\text { Kategori } \\
\text { Kevalidan }\end{array}$ \\
\hline 77 & $96,25 \%$ & Sangat Valid \\
\hline
\end{tabular}

Perolehan skor penilaian validator sebanyak 77, skor tersebut kemudian dianalisis dengan menggunakan teknis analisis data presentase yaitu skor yang diperoleh dibagi dengan skor maksimal kemudian dikonversi dalam bentuk presentase. Skor maksimal dalam penilaian multimedia interaktif ini adalah 80 . Setelah dikonversi dalam bentuk presentase, skor menjadi 96,25\%. Menurut Suparno dalam Harumi (2014), presentase tersebut menunjukkan bahwa multimedia interaktif yang telah disusun masuk kategori tingkat validasi yang pertama yaitu antara $80 \%$ $100 \%$, skor dan presentase kuesioner tersebut menyatakan bahwa media pembelajaran multimedia interaktif yang telah disusun memiliki kategori yang sangat valid dan siap dimanfaatkan sebagai salah media pembelajaran di SMA.

\section{Penerapan Multimedia Interaktif Hasil Penelitian dalam Pembelajaran}

Proses dan produk adalah media pembelajaran berupa multimedia interaktif yang dalam hal ini dapat dimanfaatkan sebagai salah satu alternatif media pembelajaran di SMA/MA sebagai sumber belajar biologi khususnya pada materi invertebrata. Media pembelajaran ini dapat diterapkan di dalam kelas dengan memanfaatkan multimedia interaktif sebagai bahan ajar pada saat pembelajaran sesuai dengan materi atau KD 3.8 yang telah tertulis pada silabus.

Penggunaan multimedia interaktif sebagai bahan ajar di sekolah sedapat mungkin berdasarkan pada landasan pokok yaitu kurikulum 2013. Kelebihan dari media pembelajaran ini adalah gabungan dari Microsoft powerpoint, video, gambar, teks, dan interaksinya. Selain itu, multimedia interaktif ini juga dilengkapi dengan kuis interaktif yang menjadi salah satu keunggulan dari media ini. Soal evaluasi bersifat interaktif dalam media yaitu siswa dapat langsung menggerjakan soal evaluasi dan langsung dapat mengetahui hasilnya.

Media pembelajaran berupa multimedia ini berisi tentang materi invertebrata mata pelajaran biologi kelas X SMA semester genap.

\section{KESIMPULAN DAN SARAN}

Berdasarkan data pengamatan dan hasil pembahasan maka dapat disimpulkan bahwa jenis-jenis hewan invertebrata ditemukan di Kawasan Pantai Ngeden yang dapat digunakan sebagai penyusunan media pembelajaran berupa multimedia interaktif terdiri atas 18 spesies.

Produk penelitian ini merupakan multimedia yang sudah dilakukan proses validasi oleh ahli materi, ahli media dan guru biologi. Penilaian oleh ahli materi diperoleh presentase 95,45 \% (sangat valid), penilaian ahli media diperoleh presentase 82,29 \% (sangat valid), penilaian oleh guru biologi SMA Negeri 1 Bulu diperoleh presentase $96,25 \%$ (sangat valid) sehingga multimedia interaktif ini layak untuk dimanfaatkan di Sekolah Menengah Atas sebagai media pembelajaran biologi materi Invertebrata.

\section{UCAPAN TERIMAKASIH}

Penelitian ini dapat selesai dengan baik karena bantuan dari berbagai pihak. Oleh karena itu penulis mengucapkan terima kasih kepada POKDARWIS Pantai Ngeden yang telah banyak membantu 
dalam penelitian serta SMA Negeri 1 Bulu Sukoharjo.

\section{DAFTAR PUSTAKA}

Daryanto. (2013). Media Pembelajaran: Pranannya Sangat Penting Dalam Mencapai Tujuan Pembelajaran. Yogyakarta: Gava Media.

Effendi, H. (2003). Telaah kualitas air. Kanisius. Yogyakarta.

Maryam, Siti Sudjoko. (1985). Pengajaran Biologi Secara Individual. Jakarta: UI Press.

Nybakken, J. W. (1988). Biologi Laut Suatu Pendekatan Ekologis. PT. Gramedia: Jakarta

Rusyana, A. (2011). Zoologi Invertebrata (Teori dan Praktik). Bandung : Alfabeta.

Subiyantoro, S., \& Nugroho, A. A. (2018). Pengembangan Media Pembelajaran Berbasis Android sebagai Pendukung Pembelajaran Mata Kuliah Belajar dan Pembelajaran. Edudikara: Jurnal Pendidikan dan Pembelajaran, 3(3), 275284.

Sugiyono. (2014). Metode Penelitian Kuantitatif Kualitatif dan $R \& D$. Bandung: Alfabeta.

Susanto, Pudyo. (2000). Pengantar Ekologi Hewan. Proyek Pengembangan Guru Sekolah Menegah IBRD Loan 3979. Jakarta: Direktorat Jenderal Pendidikan Tinggi Departemen Pendidikan Nasional.

Upikoh. (2008). Keanekaragaman Jenis Makrozoobenthos Pada Kawasan Mangrove Pantai Morosari Kecamatan Sayung Kabupaten Demak. Skripsi. Semarang: FMIPA UNNES. 